\title{
FINANCING OF WORKING CAPITAL REQUIREMENT, FINANCIAL FLEXIBILITY AND SME PERFORMANCE
}

\author{
Sonia BAÑOS-CABALLERO ${ }^{1}$, Pedro J. GARCÍA-TERUEL ${ }^{2}$, \\ Pedro MARTÍNEZ-SOLANO ${ }^{3}$
}

Department of Management and Finance, University of Murcia, Murcia, Spain

E-mails: ${ }^{1}$ sbanos@um.es; ${ }^{2}$ pjteruel@um.es; ${ }^{3}$ pmsolano@um.es (correspondingauthor)

Received 21 March 2014; accepted 05 August 2015

\begin{abstract}
This paper investigates the relation between the financing strategies of working capital requirement and firm performance for the period 1997 to 2012. Using the two-step generalized method of moments estimator, we find that a suitable financing strategy can help firms improve their performance. Moreover, the results indicate that the working capital requirement financing-performance relation changes during a financial crisis. Finally, we also find that this relation depends on a firm's financial flexibility. The findings are of interest for managers and researchers and show that managers should not only be concerned about investing in working capital requirement but also consider how this investment is to be financed. To the best of our knowledge, this is the first paper to analyse how the financing strategy selected by firms to finance their working capital requirement affects their performance.
\end{abstract}

Keywords: working capital requirement, short-term debt, performance, financial flexibility, financial crisis, SMEs.

JEL Classification: G30, G32.

\section{Introduction}

Since Smith (1980) suggested that working capital management is important because of its effects on the profitability, risk, and, consequently, value of a firm, the literature on investment in working capital requirement (WCR) has enjoyed extensive growth. While Chiou et al. (2006), Baños et al. (2010) and Hill et al. (2010) analyse the determinants of WCR for firms, the influence of investment in WCR on firm performance is also demonstrated by a number of publications (Deloof 2003; Lazaridis, Tryfonidis 2006; Kieschnick et al. 2013; Baños et al. 2014; among others).

Investment in WCR, however, might not be the only important concern for firms when making working capital decisions, because how WCR is financed may also affect performance. Indeed, since Modigliani and Miller (1958), extended corporate finance literature

This article has been corrected since first published. Please see the statement of correct (https://doi:10.3846/16111699.2017.1278645). 
has highlighted the importance of financing decisions and their impact on firm value. In addition, the short-term financial management literature has traditionally shown how alternative strategies in financing WCR affect profitability and risk (Van Horne 1969; Smith 1980). However, there is no empirical evidence that also analyses the possible influence of WCR financing strategies on performance. While previous works have studied how investment in WCR affects firm performance, this paper examines whether the term structure of financing used by firms to finance their WCR affects performance, where WCR is defined as the current assets net of accounts payable. In addition, we study this relation for two periods, before and during the financial crisis, which allows us to analyse how the crisis affects this relation.

When WCR requires financing, firms can seek funding either internally, through free cash flow, or externally, via long-term or short-term debt. Firms may finance a high proportion of their WCR long term, that is, they use a less risky WCR financing strategy that allows them to reduce both the refinancing and interest risk. Alternatively, firms may use a riskier WCR financing strategy, i.e., a high proportion of WCR financed with short-term debt, which might reduce their financing costs and thus allow them to enjoy better credit conditions, to mitigate agency costs and to signal their positive prospects to the market. We also investigate whether this relationship between WCR financing and firm performance is influenced by a firm's financial flexibility.

We use a sample of Spanish manufacturer SMEs for two reasons. First, Peel et al. (2000) suggest that efficient working capital management is particularly important for small and medium-sized firms due to the greater difficulties they have in obtaining funding in long-term capital markets (Petersen, Rajan 1997); hence, these SMEs exhibit greater dependence on trade credit and bank credit as sources of debt. Second, Spain provides an interesting case study because, as in most European countries, Spain has a banking-oriented financial system wherein capital markets are less developed and thus banks play an important role (Schmidt, Tyrell 1997). Thus, there is a large proportion of bank-dependent Spanish SMEs (Carbó et al. 2009), and therefore, our results may be of interest to SMEs in countries with similar financial systems.

To the best of our knowledge, this is the first paper to analyse how the WCR financing strategy selected by firms affects their performance, and the findings confirm the importance of the WCR financing strategy's influence on performance. Therefore, according to our results, investment in WCR should not be the only important concern for firms when making WCR decisions. Rather, how this investment is financed should also be considered. In addition, the WCR financing-performance relation found for the period prior to the financial crisis differs from the relation that occurs during the crisis. Analyses also reveal that both leverage and cash holding policies of firms affect the WCR financing-performance relation prior to the financial crisis.

The remainder of the paper is organized as follows. Section 1 links WCR financing and performance. Section 2 describes the empirical model and data. The results obtained for the period 1997 to 2007 are presented in Section 3, and Section 4 investigates whether the results change during the financial crisis period. We present the conclusions in the final section of the paper. 


\section{Financing WCR and firm performance}

Since Modigliani and Miller (1958) proved that, assuming perfect and frictionless capital markets, the choice between debt and equity financing has no effect on a firm's value or on the cost or availability of capital, much research has been conducted to understand firms' capital structure decisions and the corresponding effects of those decisions on firm value. Later, Stiglitz (1974) suggested that the terms of debt were also irrelevant under perfect capital markets, and thus, researchers have also sought to explain debt maturity structure (see, for instance, Antoniou et al. 2006).

A positive WCR must be financed, and hence, a greater WCR indicates the need for additional funds that firms can finance internally, using free cash flow, or externally, via long-term or short-term debt. Given the differences in costs and risks between the various sources of finance available to firms, the way in which a firm finances its WCR might affect its performance.

According to Walker (1989), as small firms rarely obtain long-term debt or equity in traditional financial markets, they rely on trade credit and bank credit as major sources of debt. Consistently, Hughes (1997) indicates that small firms are much more reliant on short-term bank loans for financing their assets than are large companies. Indeed, our data indicate that a high proportion of the total debt of Spanish manufacturing SMEs is short-term debt $(82.64 \%)$.

Although short-term bank debt enjoys several advantages, it also carries significant risks; thus, the influence of a higher percentage of WCR financed with short-term bank debt on firm performance may be either positive or negative.

Greater short-term debt might positively influence firm performance for several reasons. First, as Jun and Jen (2003) indicate, nominal rates of short-term debt are lower than those of long-term debt due to default and inflation premiums, which tend to increase as debt maturity lengthens. Second, Jun and Jen (2003) also suggest that short-term debt adapts more easily to a firm's financial needs. Third, Petersen and Rajan (1994) indicate that short-term debt facilitates bank relations between the firm and the lender due to frequent renewals, and hence, firms might obtain credit condition benefits. Fourth, short-term debt can mitigate agency conflicts between shareholders and debtholders. Empirical evidence confirms that firms can use short-term loans to solve the problem of underinvestment because management is more frequently monitored when there is periodic credit renewal (see, for example, Barclay and Smith 1995). In the case of SMEs, the problem of underinvestment can be particularly severe (MacMahon 2003). Finally, as Flannery (1986) and Kale and Noe (1990) note, firms with high-quality investment projects use short-term loans to transmit their positive prospects to the market.

However, more short-term bank debt could also negatively affect firm performance due to an increase in refinancing and higher interest risks (Jun, Jen 2003). Firms might have difficulties renewing their short-term loans, or they might have to pay higher interest rates on new loans, which would negatively affect their performance. 
Given these positive and negative effects of short-term bank debt, a greater use of shortterm bank debt to finance a firm's WCR could affect the firm's performance. When a low percentage of WCR is financed with short-term bank debt, any increase may result in an increase in firm performance because the positive influence of short-term bank debt is expected to outweigh the negative influence as firms could reduce their interest costs, obtain credit condition benefits, mitigate agency costs and signal their positive prospects to suppliers of funds. In contrast, when firms finance a high percentage of their WCR with short-term bank debt, a greater use of short-term bank debt might negatively affect performance due to interests and refinancing risks. Thus, at high percentages of WCR financed with short-term bank debt, the negative influence of short-term bank debt is expected to be the dominant factor.

Therefore, our primary hypothesis is as follows:

"There is a positive relation between the proportion of short-term bank debt used to finance a firm's WCR and its performance when a low percentage of WCR is financed with short-term bank debt. However, this relation is negative when firms finance a high percentage of their WCR with short-term bank debt".

However, this relation may differ during a financial crisis. According to Santos (2011), the financial condition of banks is important because it may influence their lending capacity and, as a consequence, affect the greater economy. He finds that firms that have borrowed during the crisis have paid more than they paid for the loans that they took out before the crisis from the same bank and that the size of the loans that firms took out during this period was also smaller. This increase in the cost and the lower availability of bank credit to firms could result in a lower performance for those firms that have had to renew their credit during the crisis period 2008 to 2012. Consistent with this, Fungocova et al. (2013) demonstrate that the crisis led to an overall decrease in credit supply. Vermoesen et al. (2013) also indicate that this lower availability of external finance has reduced investments of SMEs in Belgium (which, like Spanish SMEs, are in the eurozone).

Given the difficulties in renewing and obtaining external financing during the crisis period, we would expect the disadvantages of using short-term debt to finance the WCR to outweigh the advantages. Thus, our second hypothesis is as follows:

"The WCF-performance relation is linear and negative during the crisis period".

\section{Model and data}

\subsection{Model and methodology}

To analyse the relation between WCR financing and firm performance, we use the variable WCF as a measure of WCR financing. This is calculated using the following ratio: short-term bank debt/WCR where WCR is defined as current assets minus accounts payable. A greater WCF means riskier WCR financing, as it measures the percentage of WCR that is financed with short-term bank debt.

Thus, to test the possible non-monotonic relationship between WCF and performance, 
we regress firm performance against the WCF variable and its square. Additional variables are also included in the performance regression model to control for other potential influences on the performance of the firm. In particular, we include firm size, sales growth and leverage. We estimate the relation between WCR financing and firm performance through the following regression:

$$
\begin{aligned}
& R O E_{i, t}=\beta_{0}+\beta_{1} W C F_{i, t}+\beta_{2} W C F_{i, t}^{2}+\beta_{3} S I Z E_{i, t}+ \\
& \beta_{4} G R O W T H_{i, t}+\beta_{5} L E V_{i, t}+\lambda_{t}+\eta_{i}+\varepsilon_{i, t},
\end{aligned}
$$

where $R O E_{i, t}$ is the return on equity, which is defined as net profit/equity; $W C F_{i, t}$ is the WCR financing; and $W C F^{2}$ i,t is its square. The inclusion of these two variables allows us to test both the positive and negative effects mentioned herein. In addition, following Deloof (2003) among others, we control for firm size, growth of sales and leverage. $S I Z E_{i, t}$ is measured by the natural logarithm of total assets; GROWTH $H_{i, t}$ is calculated by the ratio $\left(\right.$ sales $_{i, t}-$ sales $\left._{i, t-1}\right) /$ sales $_{i, t-1}$; and $L E V$ is defined as the ratio of total (longterm + short-term) debt to total assets. The parameter $\lambda_{t}$ is a time dummy variable that changes with time but is equal for all firms in each of the time periods considered. This parameter is designed to capture the influence of economic factors that firms cannot control even though these factors may affect firm performance. The parameter $\eta_{i}$ is the unobservable heterogeneity or the firm's unobservable individual effects, thus allowing us to control for the particular characteristics of each firm. Finally, $\varepsilon_{i, t}$ is the random disturbance.

As our aim is to analyse the effect of WCR financing on firm performance, we only include those observations that have a positive WCR and, hence, a need for financing in our analyses. The coefficients on $\mathrm{WCF}$ and $\mathrm{WCF}^{2}$ variables obtained from Equation (1) allow us to determine the breakpoint in the WCR financing-firm performance relation, which is calculated by $-\beta_{1} / 2 \beta_{2}$. If there is a concave relationship between WCF and return on equity, the inflection point of this relationship should be a maximum; therefore, $\beta_{1}$ should be positive and $\beta_{2}$ should be negative.

We use panel data methodology to estimate our model because, first, it allows us to control for unobservable heterogeneity and therefore eliminate the risk of biased results arising from heterogeneity (Hsiao 1985), and second, it avoids the problem of possible endogeneity, as the random disturbances that affect ROE may also affect firm characteristics, for example, leverage. We estimated our models using the two-step generalized method of moments (GMM) estimator based on Arellano and Bond (1991), thus allowing us to control for endogeneity through the use of instruments. We use all the right-hand side variables in the models lagged from $t-1$.

\subsection{Data and summary statistics}

The study uses panel data of Spanish SMEs. The data were obtained from the SABI (Iberian Balance Sheets Analysis System) database, which was developed by Bureau Van Dijk and which contains accounting and financial information for Spanish firms.

The sample comprises small and medium-sized manufacturing firms from Spain for the period 1997 to 2012. The selection of SMEs was conducted according to the require- 
ments established by European Commission Recommendation 2003/361/EC of 6 May, 2003 , i.e., fewer than 250 employees, less than 50 million euro in turnover a year and less than 43 million euro in total assets. The information obtained was refined. Specifically, we eliminated firms with lost values, cases with errors in the accounting data and extreme values presented by all variables. In addition, we also required firms to have reported data for at least five consecutive years. Ultimately, we obtained an unbalanced panel of 3735 observations.

Table 1 presents the descriptive statistics on return on equity, WCF and the control variables. Table 2 provides Pearson correlations for variables in Equation (1). Moreover, to ensure that the multicollinearity problem is not present in our analysis, we calculated the variance inflation factor (VIF) for each independent variable included in our model. As the largest VIF value is far from 5, it can be concluded that multicollinearity is not a concern in the sample (Studenmund 1997).

Table 1. Summary statistics

\begin{tabular}{|c|c|c|c|c|c|}
\hline \multicolumn{6}{|c|}{$1997-2007$} \\
\hline & Mean & Standard deviation & 10th & Median & 90th \\
\hline ROE & 0.0738 & 0.1159 & -0.0268 & 0.0730 & 0.1919 \\
\hline WCF & 0.4719 & 0.3732 & 0.0507 & 0.4191 & 0.9076 \\
\hline SIZE & 9.1281 & 0.6096 & 8.3367 & 9.1072 & 9.9633 \\
\hline GROWTH & 0.0766 & 0.1615 & -0.0887 & 0.0606 & 0.2538 \\
\hline LEV & 0.5912 & 0.1861 & 0.3204 & 0.6126 & 0.8239 \\
\hline \multicolumn{6}{|c|}{$2008-2012$} \\
\hline & Mean & Standard deviation & 10th & Median & 90th \\
\hline ROE & 0.0356 & 0.0663 & -0.0360 & 0.0321 & 0.1111 \\
\hline WCF & 0.3222 & 0.2225 & 0.0489 & 0.2988 & 0.6341 \\
\hline SIZE & 9.2381 & 0.4928 & 8.5733 & 9.2646 & 9.8772 \\
\hline GROWTH & -0.0198 & 0.1370 & $-0.2031 \mathrm{~h}$ & -0.0135 & 0.1565 \\
\hline LEV & 0.5030 & 0.1572 & 0.2834 & 0.5092 & 0.7038 \\
\hline
\end{tabular}

Note: ROE represents the return on equity; WCF is the ratio of short-term bank debt/WCR; SIZE refers to size; GROWTH refers to sales growth; and LEV refers to leverage.

Table 2. Correlation matrix

\begin{tabular}{lccccc}
\hline \multicolumn{5}{c}{$1997-2007$} \\
\hline ROE & ROE & WCF & SIZE & GROWTH & LEV \\
\hline WCF & 1.0000 & & & & \\
\hline SIZE & $-0.0768^{* * *}$ & 1.0000 & & & \\
\hline GROWTH & $-0.1058^{* * *}$ & 0.0159 & 1.0000 & & \\
\hline LEV & $0.2045^{* * *}$ & $0.1049^{* * *}$ & $0.0646^{* * *}$ & 1.0000 & \\
\hline
\end{tabular}


End of Table 2

\begin{tabular}{lccccc}
\hline \multicolumn{5}{c}{$2008-2012$} \\
\hline ROE & ROE & WCF & SIZE & GROWTH & LEV \\
\hline WCF & 1.0000 & & & & \\
\hline SIZE & $-0.1803^{* * *}$ & 1.0000 & & & \\
\hline GROWTH & $0.0830^{* * *}$ & $0.1059^{* * *}$ & 1.0000 & & \\
\hline LEV & $0.2809^{* * *}$ & 0.0225 & $0.1183^{* * *}$ & 1.0000 & \\
\hline
\end{tabular}

Note: ROE represents the return on equity; WCF is the ratio of short-term bank debt/WCR; SIZE refers to size; GROWTH refers to sales growth; and LEV refers to leverage; ***indicates significance at $1 \%$ level.

\section{Empirical evidence for the period 1997 to 2007}

\subsection{Working capital requirement financing and firm performance}

We explore the effect of WCR financing on firm performance by estimating the Model (1) proposed in Section 2. The results are presented in Column (1) of Table 3. Our findings indicate that $\beta_{1}$ is positive and $\beta_{2}$ is negative and that both coefficients are significant, thus confirming a concave relation between WCF and firm performance. When a low percentage of WCR is financed with short-term bank debt, firms may improve their performance with riskier WCR financing due to the advantages associated with short-term bank debt. Specifically, firms might reduce their interest costs, obtain credit condition benefits, mitigate agency costs and signal their positive prospects to suppliers of funds.

In contrast, when firms finance a high percentage of their WCR with short-term bank debt, riskier WCR financing negatively affects firm performance because the negative influence of short-term bank debt outweighs the positive influence. Although firms enjoy several advantages with short-term debt, this also implies interest and refinancing risks, which can, in turn, cause high financial distress costs (Jun, Jen 2003). Thus, at sufficiently high WCF levels, the negative influence of riskier WCR financing is the dominant factor ${ }^{1}$. Our results suggest that, for our sample, the WCF-firm performance relationship has a breakpoint of approximately 0.62 .

In Column (2), following Ghosh and Moon (2010), we use an alternative research design based on spline regressions to give robustness to the results obtained from Equation (1). We estimate the following model:

$$
\begin{aligned}
& R O E_{i, t}=\beta_{0}+\beta_{1} W C F_{(0,0.62) i, t}+\beta_{2} W C F_{(0.62, \mathrm{Max}) i, t}+\beta_{3} S I Z E_{i, t}+ \\
& \beta_{4} \operatorname{GROWTH}_{i, t}+\beta_{5} L E V_{i, t}+\lambda_{t}+\eta_{i}+\varepsilon_{i, t},
\end{aligned}
$$

\footnotetext{
${ }^{1}$ We also obtain this concave relation between WCF and firm performance if we measure the WCF variable by the ratio of short-term bank debt/(accounts receivable + inventories - accounts payable). Furthermore, the results do not change when we use the ratio of net profit to sales as a measure of firm performance.
} 
where we replace the $W C F$ variable and its square $\left(W C F^{2}\right)$ with $W C F_{(0,0.62)}$ and $W C F_{(0.62, \mathrm{Max})}$. We use the breakpoint obtained from Equation (1) to divide $W C F$ into low and high range categories. In particular, $W C F_{(0,0.62)}$ equals $W C F$ if $W C F$ lies between 0 and 0.62 , and it equals 0.62 otherwise. $W C F_{(0.62, \text { Max })}$ equals $W C F$ minus 0.62 if $W C F$ is greater than 0.62 , and 0 otherwise. All other variables are the same as those specified in Equation (1).

Consistent with the findings presented in Column (1), the results obtained from Equation (2) indicate that there is a concave relation between $\mathrm{WCF}$ and a firm performance given that the coefficient for $W C F_{(0,0.62)}$ is positive and significant, but that for $W C F_{(0.62 \text {, }}$ Max) is negative and significant. The results indicate that a riskier WCR financing strategy has a positive influence on performance at low levels of the WCF ratio but that this effect becomes negative at high levels of the ratio.

Table 3. Financing of working capital requirement and SME performance (1997-2007)

\begin{tabular}{|c|c|c|}
\hline & Eq. (1) & Eq. (2) \\
\hline WCF & $\begin{array}{c}0.0894 * * * \\
(9.49)\end{array}$ & \\
\hline $\mathrm{WCF}^{2}$ & $\begin{array}{c}-0.0722 * * * \\
(-16.09)\end{array}$ & \\
\hline $\mathrm{WCF}_{(0,0.62)}$ & & $\begin{array}{c}0.0645^{* * *} \\
\quad(3.27)\end{array}$ \\
\hline $\mathrm{WCF}_{(0.62, \mathrm{Max})}$ & & $\begin{array}{c}-0.1135^{* * *} \\
(-9.22)\end{array}$ \\
\hline SIZE & $\begin{array}{c}-0.0558 * * * \\
(-6.33)\end{array}$ & $\begin{array}{c}-0.0869^{* * *} \\
(-5.80)\end{array}$ \\
\hline GROWTH & $\begin{array}{c}0.1230^{* * *} \\
(12.67)\end{array}$ & $\begin{array}{c}0.1181 * * * \\
(9.73)\end{array}$ \\
\hline LEV & $\begin{array}{c}-0.1326^{* * *} \\
(-4.78)\end{array}$ & $\begin{array}{c}-0.1479 * * * \\
(-3.85)\end{array}$ \\
\hline$M_{2}$ & -1.60 & -1.34 \\
\hline Hansen Test & $238.69(220)$ & $247.99(220)$ \\
\hline Observations & 3735 & 3735 \\
\hline
\end{tabular}

Notes: The dependent variable is firm performance; WCF is measured by the ratio of short-term bank debt/WCR; SIZE refers to size; GROWTH refers to sales growth; and LEV refers to leverage. $\mathrm{WCF}_{(0,0.62)}$ equals $W C F$ if $W C F$ lies between 0 and 0.62 , and 0.62 otherwise. $W C F_{(0.62, \text { Max }}$ equals $W C F$ minus 0.62 if $W C F$ is greater than 0.62 , and 0 otherwise. Time dummies are included in the estimations but not reported. $Z$ statistics are in brackets. $m_{2}$ is a serial correlation test of second-order using residuals of first differences, asymptotically distributed as $\mathrm{N}(0,1)$ under the null hypothesis of no serial correlation. Hansen test is a test for over-identifying restrictions distributed asymptotically under the null hypothesis of the validity of instruments as Chi-squared. Degrees of freedom are in brackets. $*$ indicates significance at $10 \%$ level, $* *$ indicates significance at $5 \%$ level, and $* * *$ indicates significance at $1 \%$ level. 


\subsection{Firm financial flexibility and financing working capital requirement}

According to previous results, there is a percentage of WCR financed with short-term bank debt beyond which the relation between WCF and performance becomes negative. This section explores whether the breakpoint of this WCF-performance relation depends on a firm's financial flexibility.

The literature has defined financial flexibility as the ability of a firm to access and restructure its financing at a low cost (Gamba, Triantis 2008; Byoun 2008). Thus, one might expect that firms with greater flexibility can finance a greater portion of their WCR with short-term bank debt without damaging their performance.

Prior research analyses how firms obtain financial flexibility through low-leverage policies (see, for example, Byoun 2008) and high cash holding policies (Faulkender, Wang 2006, among others). The bulk of the literature in this area separately studies cash and leverage policies. As a consequence, we consider leverage and cash holdings as proxies for the financial flexibility of a firm. Specifically, we first classify firms according to the ratio of total debt to total assets and consider firms with a lower ratio than the sample median as firms with greater financial flexibility. Second, we categorize firms according to the ratio of cash and equivalents to total assets and consider those firms with a greater ratio than the sample median as firms with more financial flexibility. Finally, for greater robustness, we simultaneously investigate these two policies by combining both debt financing and liquidity decisions to measure a firm's financial flexibility. Firms are classified as being financially flexible if they hold both low leverage and high cash reserves at the same time. In particular, we define a firm as financially flexible if its total debt to total assets ratio is in the bottom $75 \%$ of all firms and, at the same time, its cash and equivalents to total assets ratio is in the top $75 \%$ of all firms. We find for our sample that $64.6 \%$ of all observations fulfil both requirements simultaneously.

To test whether the breakpoint of the WCR financing-performance relation varies according to the financial flexibility of a firm, Equation (1) is extended by incorporating a dummy variable that distinguishes between firms that are more and less financially flexible. DUM is a dummy variable that takes a value of 1 for firms with greater financial flexibility, and 0 otherwise. Thus, we estimate the following model:

$$
\begin{aligned}
& R O E_{i, t}=\beta_{0}+\left(\beta_{1}+\delta_{1} D U M_{i, t}\right) W C F_{i, t}+\left(\beta_{2}+\delta_{2} D U M_{i, t}\right) W C F_{i, t}^{2}+ \\
& \beta_{3} S_{Z I E}+E_{i, t}+\beta_{4} \text { GROWTH }_{i, t}+\beta_{5} L E V_{i, t}+\lambda_{t}+\eta_{i}+\varepsilon_{i, t} .
\end{aligned}
$$

All dependent and independent variables are as previously defined. By construction, the expression $-\beta_{1} / 2 \beta_{2}$ measures the breakpoint of the WCF-performance relation for firms with less financial flexibility. The breakpoint of this relation for firms that have greater flexibility is captured by the expression $-\left(\beta_{1}+\delta_{1}\right) / 2\left(\beta_{2}+\delta_{2}\right)$.

The results, which are presented in Table 4 , confirm our hypothesis that the relationship between WCF and performance is concave. In addition, the breakpoint for firms that have greater financial flexibility occurs at higher levels of the WCF variable. That 
is, our findings indicate that these firms can finance a greater percentage of their WCR with short-term bank debt without harming their performance, a finding that may be due to their lower refinancing and interest risks given that they are expected to be able to access and restructure their financing at a low cost.

Table 4. Financing of working capital requirement and financial flexibility (1997-2007)

\begin{tabular}{lccc}
\hline & Leverage & Cash & Leverage and cash \\
\hline WCF & $0.0709^{* * *}$ & $0.0614^{* * *}$ & $0.0186^{* * *}$ \\
& $(9.65)$ & $(14.25)$ & $(2.59)$ \\
\hline WCF*DUM & -0.0025 & $0.1360^{* * *}$ & $0.0507^{* * *}$ \\
& $(-0.29)$ & $(15.10)$ & $(5.14)$ \\
\hline WCF $^{2}$ & $-0.0618^{* * *}$ & $-0.0531^{* * *}$ & $-0.0503 * * *$ \\
& $(-18.60)$ & $(-30.99)$ & $(-18.67)$ \\
\hline WCF $^{2 * D U M}$ & $0.0202^{* *}$ & $-0.0486^{* * *}$ & $0.0295^{* * *}$ \\
& $(2.46)$ & $(-9.84)$ & $(4.81)$ \\
\hline SIZE & $-0.0333^{* * *}$ & $-0.0489 * * *$ & $-0.0399^{* * *}$ \\
& $(-5.62)$ & $(-11.95)$ & $(-10.23)$ \\
\hline GROWTH & $0.1062^{* * *}$ & $0.1154 * * *$ & $(24.18)$ \\
\hline LEV & $(18.08)$ & $(23.26)$ & $-0.0918^{* * *}$ \\
& $-0.0515^{* * *}$ & $-0.1844^{* * *}$ & $(-7.89)$ \\
\hline$F_{1}$ & $(-2.89)$ & $(-10.34)$ & 129.54 \\
\hline$F_{2}$ & 53.33 & 368.42 & 19.92 \\
\hline$m_{2}$ & 27.15 & 412.63 & -1.18 \\
\hline Hansen Test & -1.75 & -1.08 & $317.96(308)$ \\
\hline Observations & 3735 & $332.90(308)$ & \\
\hline Notes: & & 3735 & \\
\hline
\end{tabular}

Notes: The dependent variable is firm performance; WCF is measured by the ratio of short-term bank debt/WCR; SIZE refers to size; GROWTH refers to sales growth; and LEV refers to leverage. DUM is a dummy variable equal to 1 for firms with more financial flexibility. Time dummies are included in the estimations but not reported. $\mathrm{Z}$ statistics are in brackets. $F_{1}$ is a F-test for the linear restriction test under the following null hypothesis: $\mathrm{H}_{0}:\left(\beta_{1}+\delta_{1}\right)=0 . F_{2}$ is an F-test for the linear restriction test under the following null hypothesis: $\mathrm{H}_{0}:\left(\beta_{2}+\delta_{2}\right)=0 . m_{2}$ is a serial correlation test of second-order using residuals of first differences, asymptotically distributed as $\mathrm{N}(0,1)$ under the null hypothesis of no serial correlation. Hansen test is a test for over-identifying restrictions distributed asymptotically under the null hypothesis of the validity of instruments as Chi-squared. Degrees of freedom are in brackets. $*$ indicates significance at $10 \%$ level, $* *$ indicates significance at $5 \%$ level, and $* * *$ indicates significance at $1 \%$ level. 


\section{The effect of the financial crisis on the relation between WCR financing and firm performance}

Having found that there is a concave relation between the variable for WCF and firm performance for the period 1997 to 2007 and that the breakpoint of this relation depends on firm financial flexibility, this section examines whether these results also hold during the financial crisis (2008 to 2012).

As previously mentioned, given the difficulties in renewing and obtaining external financing during the crisis period, we would expect the disadvantages of using short-term debt to finance WCR to outweigh the advantages. Thus, the WCF-performance relation could be linear and negative during the crisis.

Accordingly, we analyse the relation between WCF and ROE by estimating both a quadratic and a linear model to ascertain whether the relation between the variables is linear or quadratic. Column (1) of Table 5 presents the results obtained by estimating the model (1) proposed in Section 2 (quadratic model). In column (2), we estimate a linear relation by eliminating the variable $\mathrm{WCF}^{2}$.

Table 5. Financing of working capital requirement and SME performance (2008-2012)

\begin{tabular}{lcc}
\hline & Eq. $(1)$ & Eq. $(2)$ \\
\hline WCF & -0.1059 & $-0.1152^{* * *}$ \\
& $(-1.27)$ & $(-3.25)$ \\
\hline WCF $^{2}$ & -0.0083 & \\
& $(-0.09)$ & $-0.1562^{* * *}$ \\
\hline SIZE & $-0.1439 * * *$ & $(-2.85)$ \\
& $(-2.87)$ & 0.0247 \\
GROWTH & $0.0230^{*}$ & $(1.61)$ \\
\hline LEV & $(1.67)$ & $0.4090^{* * *}$ \\
& $0.3853^{* * *}$ & $(3.07)$ \\
\hline$M_{2}$ & $(3.22)$ & -1.06 \\
\hline Hansen Test & -1.09 & $46.57(36)$ \\
\hline Observations & $51.49(45)$ & 1128 \\
\hline
\end{tabular}

Note: The dependent variable is firm performance; WCF is measured by the ratio of short-term bank debt/WCR; SIZE refers to the size; GROWTH refers to sales growth; and LEV refers to leverage. Time dummies are included in the estimations but not reported. $Z$ statistics are in brackets. $m_{2}$ is a serial correlation test of second-order using residuals of first differences, asymptotically distributed as $\mathrm{N}(0,1)$ under the null hypothesis of no serial correlation. Hansen test is a test for over-identifying restrictions distributed asymptotically under the null hypothesis of the validity of instruments as Chi-squared. Degrees of freedom are in brackets. *indicates significance at $10 \%$ level, $* *$ indicates significance at $5 \%$ level, and $* * *$ indicates significance at $1 \%$ level. 
The results show that during the crisis period (2008 to 2012) there is a linear and negative relation between the variables WCF and ROE. That is, firms that use less short-term bank debt to finance their WCR realize a greater return on equity, and furthermore, an increase in the percentage of WCR financed with short-term bank debt negatively affects a firm's performance ${ }^{2}$.

Finally, we study the possible effect of financial flexibility on the WCF-ROE relation. The linear model is extended by incorporating a dummy variable that distinguishes between firms that are more and less financially flexible according to the three criteria presented in Section (3.2).

The results, which are presented in Table 6, demonstrate that during the current financial crisis the financial flexibility of a firm does not affect the WCF-ROE relation. That is, Spanish SMEs with a greater percentage of their WCR financed with short-term bank

Table 6. Financing of working capital requirement and financial flexibility (2008-2012)

\begin{tabular}{lccc}
\hline WCF & Leverage & Cash & \begin{tabular}{c} 
leverage and cash \\
\hline WCF*DUM
\end{tabular} \\
\hline $\begin{array}{c}-0.1231^{* * *} \\
(-3.30)\end{array}$ & $\begin{array}{c}0.0183 \\
(0.83)\end{array}$ & $\begin{array}{c}-0.1251^{* * *} \\
(-3.92)\end{array}$ & $\begin{array}{c}-0.1198^{* * *} \\
(-3.61)\end{array}$ \\
\hline SIZE & $\begin{array}{c}-0.1343^{* * *} \\
(-2.60)\end{array}$ & $\begin{array}{c}-0.0043 \\
(-0.34)\end{array}$ & $\begin{array}{c}0.0014 \\
(0.08)\end{array}$ \\
\hline GROWTH & $\begin{array}{c}0.0303^{* *} \\
(2.09)\end{array}$ & $\begin{array}{c}-0.1369^{* * *} \\
(-2.83)\end{array}$ & $\begin{array}{c}-0.1232^{* *} \\
(-2.45)\end{array}$ \\
\hline LEV & $\begin{array}{c}0.3540^{* * *} \\
(3.05)\end{array}$ & $\begin{array}{c}0.0300^{* *} \\
(2.22)\end{array}$ & $\begin{array}{c}0.0347^{* *} \\
(2.45)\end{array}$ \\
\hline$F_{1}$ & 10.84 & $\begin{array}{c}0.3162^{* * *} \\
(2.88)\end{array}$ & $\begin{array}{c}0.3045^{* * *} \\
(2.69)\end{array}$ \\
\hline$m_{2}$ & -1.11 & 15.70 & 10.86 \\
\hline Hansen Test & $52.43(45)$ & -1.14 & -1.13 \\
\hline Observations & 1128 & $53.18(45)$ & $58.91(45)$ \\
\hline
\end{tabular}

Note: The dependent variable is firm performance; WCF is measured by the ratio of short-term bank debt/WCR; SIZE refers to size; GROWTH refers to sales growth; and LEV refers to leverage. DUM is a dummy variable equal to 1 for firms with more financial flexibility. Time dummies are included in the estimations but not reported. $Z$ statistics are in brackets. $F_{1}$ is an F-test for the linear restriction test under the following null hypothesis: $\mathrm{H}_{0}:\left(\beta_{1}+\delta_{1}\right)=0 . m_{2}$ is a serial correlation test of second-order using residuals of first differences, asymptotically distributed as $\mathrm{N}(0,1)$ under the null hypothesis of no serial correlation. Hansen test is a test for over-identifying restrictions distributed asymptotically under the null hypothesis of validity of instruments as Chi-squared. Degrees of freedom are in brackets. *indicates significance at $10 \%$ level, $* *$ indicates significance at $5 \%$ level, and $* * *$ indicates significance at $1 \%$ level.

${ }^{2}$ We also find a linear and negative relation between WCF and performance if we use the ratio net profit to sales as a measure of firm performance. 
debt are those with the lowest return on equity, regardless of their debt financing and liquidity policies. It further seems that during this period, the lower availability of bank credit to firms and the higher cost of this credit also affects those SMEs with financial flexibility. Thus, contrary to the results obtained for the period prior to the crisis, we find that, regardless of the debt financing and liquidity decisions made by firms, the most profitable SMEs are those with the lowest percentage of WCR financed with short-term bank debt.

\section{Conclusions}

This paper analyses the relation between WCR financing and firm performance for a sample of small and medium-sized manufacturing firms for the period 1997 to 2012 . Although there is a wealth of literature on the effect of investment in WCR on firm performance, the possible influence of WCR financing on performance is a topic that has yet to be explored. Hence, this paper examines whether the way in which a firm finances its WCR also influences its performance. In addition, this relation is studied for two different periods, before and during the financial crisis, thus allowing us to analyse how a financial crisis affects the relation. To control for unobservable heterogeneity and for possible endogeneity problems, we use a panel data model and employ the two-step generalized method of moments (GMM) estimator.

Our results indicate that a suitable WCR financing strategy can help firms improve their performance. In particular, we find that for the period 1997 to 2007, firms with a low percentage of WCR financed with short-term bank debt may improve their performance by increasing this percentage due to the advantages associated with short-term bank debt. However, in the case of firms with a high percentage of WCR financed with short-term bank debt, an increase in this percentage might negatively affect their performance because of the higher interest and the refinancing risk. We also find that the WCR financing-performance relation changes during a financial crisis (2008 to 2012). Our results show that firms with a lower percentage of WCR financed with short-term debt are the most profitable firms during this period. Additional analyses also reveal that this WCR financing-performance relation depends on the firm's financial flexibility.

Our findings have potentially important implications for the literature on working capital management and for managers. On one hand, this is the first paper to analyse how the financing strategy selected by firms to finance their working capital requirement affects their performance, an analysis that might be useful for subsequent studies. On the other hand, the evidence found is also of interest for managers as it shows that managers should not only be concerned about investment in WCR but also be concerned about how this investment is financed.

As financing options and methods vary between small and large firms due to their differences in ownership structure, flexibility and taxes (Heyman et al. 2003), it is suggested that further research focused on quoted companies or different financial systems be conducted. 


\section{Acknowledgements}

This research is part of the project ECO2013-47486-P financed by the Research Agency of the Spanish government The authors also acknowledge financial support from Fundación CajaMurcia.

\section{References}

Antoniou, A.; Guney, Y.; Paudyal, K. 2006. The determinants of debt maturity structure: evidence from France, Germany and the UK, European Financial Management 12(2): 161-194.

http://dx.doi.org/10.1111/j.1354-7798.2006.00315.x

Arellano, M.; Bond, S. 1991. Some test of specification for panel data: Monte Carlo evidence and an application to employment equations, Review of Economics Studies 58(2): 277-297.

http://dx.doi.org/10.2307/2297968

Baños-Caballero, S.; García-Teruel, P. J.; Martínez-Solano, P. 2010. Working capital management in SMEs, Accounting and Finance 50(3): 511-527.

http://dx.doi.org/10.1111/j.1467-629X.2009.00331.x

Baños-Caballero, S.; García-Teruel, P. J.; Martínez-Solano, P. 2014. Working capital management, corporate performance, and financial constraints, Journal of Business Research 67(3): 332-338. http://dx.doi.org/10.1016/j.jbusres.2013.01.016

Barclay, M. J.; Smith, C. W. 1995. The maturity structure of corporate debt, Journal of Finance 50(2): 609-631. http://dx.doi.org/10.2307/2329421

Byoun, S. 2008. How and when do firms adjust their capital structures toward targets?, Journal of Finance 63(6): 3069-3096. http://dx.doi.org/10.1111/j.1540-6261.2008.01421.x

Carbó, S.; Rodriguez, F.; Udell, G. 2009. Bank market power and SME financing constraints, Review of Finance 13(2): 309-340. http://dx.doi.org/10.1093/rof/rfp003

Chiou, J. R.; Cheng, L.; Wu, H. W. 2006. The determinants of working capital management, Journal of American Academy of Business 10(1): 149-155.

Deloof, M. 2003. Does working capital management affect profitability of Belgian firms?, Journal of Business, Finance and Accounting 30(3-4): 573-587.

http://dx.doi.org/10.1111/1468-5957.00008

Faulkender, M.; Wang, R. 2006. Corporate financial policy and the value of cash, Journal of Finance 61(4): 1957-1990. http://dx.doi.org/10.1111/j.1540-6261.2006.00894.x

Flannery, M. J. 1986. Asymmetric information and risky debt maturity choice, Journal of Finance 41(1): 19-37. http://dx.doi.org/10.2307/2328342

Fungocova, Z.; Herrala, R.; Weill, L. 2013. The influence of bank ownership on credit supply: evidence from the recent financial crisis, Emerging Markets Review 15: 136-147.

http://dx.doi.org/10.1016/j.ememar.2013.02.002

Gamba, A.; Triantis, A. 2008. The value of financial flexibility, Journal of Finance 63(5): 22632296. http://dx.doi.org/10.1111/j.1540-6261.2008.01397.x

Ghosh, A.; Moon, D. 2010. Corporate debt financing and earnings quality, Journal of Business Finance \& Accounting 37(5-6): 538-559. http://dx.doi.org/10.1111/j.1468-5957.2010.02194.x

Heyman, D.; Deloof, M.; Ooghe, H. 2003. The debt maturity structure of small firms in a creditor oriented environment, in European Financial Management Association, 2003, Helsinki.

Hill, M. D.; Kelly, G.; Highfield, M. J. 2010. Net operating working capital behaviour: a first look, Financial Management 39(2): 783-805. http://dx.doi.org/10.1111/j.1755-053X.2010.01092.x 
Hsiao, C. 1985. Benefits and limitations of panel data, Econometrics Review 4(1): 121-174. http://dx.doi.org/10.1080/07474938508800078

Hughes, A. 1997. Finance for SMEs: a U.K. perspective, Small Business Economics 9(2): 151166. http://dx.doi.org/10.1023/A:1007971823255

Jun, S. G.; Jen, F. C. 2003. Trade-off model on debt maturity structure, Review of Quantitative Finance and Accounting 20(1): 5-34. http://dx.doi.org/10.1023/A:1022190205033

Kale, J. R.; Noe, T. H. 1990. Risky debt maturity choice in a sequential game equilibrium, Journal of Financial Research 13(2): 155-165. http://dx.doi.org/10.1111/j.1475-6803.1990.tb00545.x

Kieschnick, R.; LaPlante, M.; Moussawi, R. 2013. Working capital management and shareholders' wealth, Review of Finance 17(5): 1857-1852. http://dx.doi.org/10.1093/rof/rfs043

Lazaridis, I.; Tryfonidis, D. 2006. Relationship between working capital management and profitability of listed companies in the Athens stock exchange, Journal of Financial Management and Analysis 19(1): 26-35.

MacMahon, R. 2003. An exploratory study of under and over investment amongst manufacturing SMEs from Australia's business longitudinal survey, International Small Business Journal 21(1): 29-53. http://dx.doi.org/10.1177/0266242603021001720

Modigliani, F.; Miller, M. H. 1958. The cost of capital, corporation finance and the theory of investment, American Economic Review 48: 261-297.

Peel, M. J.; Wilson, N.; Howorth, C. 2000. Late payment and credit management in the small firm sector: some empirical evidence, International Small Business Journal 18(2): 17-37.

http://dx.doi.org/10.1177/0266242600182001

Petersen, M. A.; Rajan, R. G. 1994. The benefits of lending relationships: evidence from small business data, Journal of Finance 49(2): 3-37. http://dx.doi.org/10.2307/2329133

Petersen, M.; Rajan, R. 1997. Trade credit: theories and evidence, Review of Financial Studies 10(3): 661-691.

Santos, J. A. 2011. Bank corporate loan pricing following the subprime crisis, Review of Financial Studies 24(6): 1917-1943. http://dx.doi.org/10.1093/rfs/hhq115

Schmidt, R.; Tyrell, M. 1997. Financial systems, corporate finance and corporate governance, European Financial Management 3(3): 333-361. http://dx.doi.org/10.1111/1468-036X.00047

Smith, K. 1980. Profitability versus liquidity tradeoffs in working capital management, in K. V. Smith (Ed.). Readings on the management of working capital. St Paul, MN: West Publishing Company, 549-562.

Stiglitz, J. 1974. On the irrelevance of corporate financial policy, American Economic Review 64(6): 851-866.

Studenmund, A. H. 1997. Using econometrics: a practical guide. New York: Addison-Wesley.

Van Horne, J. C. 1969. A risk and return analysis of a firm's working capital position, Engineering Economist 14(2): 71-89. http://dx.doi.org/10.1080/00137916908928796

Vermoesen, V.; Deloof, M.; Laveren, E. 2013. Long-term debt maturity and financing constraints of SMEs during the global financial crisis, Small Business Economics 41(2): 433-448.

http://dx.doi.org/10.1007/s11187-012-9435-y

Walker, D. 1989. Financing the small firm, Small Business Economics 1(4): 285-296.

http://dx.doi.org/10.1007/BF00393807 
Sonia BAÑOS-CABALLERO is Associate Professor of Finance in the Department of Management and Finance at University of Murcia (Spain). Her current research interests include corporate finance and short-term financial management. She has published her research in different international journals including: Accounting and Finance, European Journal of Finance, Journal of Business Research and Small Business Economics.

Pedro J. GARCÍA-TERUEL is Associate Professor of Finance in the Department of Management and Finance, University of Murcia (Spain). His current research interests focus on corporate finance, short-term financial management, and small business finance. He has published his research in different international journals including: Accounting and Finance, European Financial Management, European Journal of Finance, Journal of Banking and Finance, Journal of Business Finance and Accounting, Small Business Economics.

Pedro MARTíNEZ-SOLANO is Professor of Finance in the Department of Management and Finance at the University of Murcia (Spain). His current research interests focus on corporate finance, shortterm financial management, and small business finance. He has published his research in different international journals including: Accounting and Finance, European Financial Management, European Journal of Finance, Journal of Banking and Finance, Journal of Business Finance and Accounting, Small Business Economics. 